\title{
11 THE NATIONAL POLICY ON RELIGION AND EDUCATION, AND RELIGIOUS DRESS OBSERVANCES IN SOUTH AFRICAN SCHOOLS
}

\section{Abdulkader Tayob ${ }^{1}$}

\section{INTRODUCTION}

In 2003, the South African Minister of Education, Kader Asmal, proclaimed a National Policy on Religion and Education (NPRE) for the teaching of religion in public and independent schools in South Africa. The new policy came at the end of almost a decade of public debate and deliberation on the value of religion in schools. ${ }^{2}$ The NPRE proposed some clear guidelines on the teaching of religion as an educational activity for a nation marked by diversity. It set aside decades of an apartheid policy that promoted and favoured Christian National Education. But the NPRE did not proscribe religious practices and religious observances in schools. ${ }^{3}$ It empowered School Governing Bodies, together with religious authorities, to set up local policies guided by the constitutional values of equity and respect for diversity.

This dual aspect of the NPRE, accommodating religious observances in schools, while focusing on a new educational approach to teaching religion, has led to an unexpected anomaly. While most schools maintain an ethos where Christian hymns, prayers and homilies occupy a dominant place in assemblies and school associations, learners from minority religious traditions have been routinely suspended or dismissed for displaying attire that they claimed formed part of their religious practices and obligations. Such religious attire and dress have been rejected for not conforming to school dress codes. A sample of such issues indicates the extensiveness of this phenomenon. In 2002, a learner at Settler's High School in the Western Cape was suspended for five days for wearing a cap and dreadlocks in conformity with her Rastafarian conviction. ${ }^{4}$ Sunali Pillay,

1 Professor, Department of Religious Studies, University of Cape Town, South Africa. This work is based on the research supported in part by the National Research Foundation of South Africa (Reference number (UID) 85397). The opinions, findings and conclusions or recommendations expressed are that of the author, and the NRF accepts no liability whatsoever in this regard.

2 Chidester D. 2006. "Religion Education and the Transformational State in South Africa", Social Analysis: The International Journal of Cultural and Social Practice 50(3): 61-83.

3 National Policy on Religion and Education (NPRE), 2003. Online at: http://www. gov.za/sites/www.gov.za/files/religion_0.pdf, para 59.

4 Roos R. 2003. "Physical Appearance of Learners in Public Schools - Antonie V Governing Body, Settlers High School 20024 Sa 738 (C)", Tydskrif vir die SuidAfrikaanse Reg [Journal of South African Law] 4:792-796. 
a Grade 11 learner at the Durban Girls High School, was suspended in 2005 for wearing a nose stud in conformity with Hindu practice. ${ }^{5}$ In 2010, Lerato Motshabi was ordered to cut the dreadlocks on her head or face expulsion at Navalsig High School in Bloemfontein in the Free State. ${ }^{6}$ In 2011, Odwa Sitayaya faced the same threat for wearing dreadlocks at Joe Slovo Engineering High School in the Western Cape. ${ }^{7}$ In 2013, the Leseding Technical Secondary School in the Free State demanded that Lerato Radebe cut her dreadlocks before being admitted into class. In 2013 and 2014, two schools in Cape Town were forced to revise their uniform policy to accommodate learners wearing headscarves. ${ }^{8}$ Three of these cases, all of them involving girls, were serious enough to be taken up by parents or by members of the Department of Education with the highest courts of the land. ${ }^{9}$

These controversies point to a significant articulation of the NPRE at schools. Looking closely at two of these controversies that have been taken up in South African courts since the promulgation of the NPRE, this essays examine how school administrators, parent bodies and the courts of the land have responded to these irregular and unfamiliar religious practices. The media reports, combined with the court records, show a general reluctance on the part of schools and parent bodies to promote or allow cultural and religious diversity in schools. Dress and uniform codes are rigidly monitored and justified, and indicate a bias against minority religious expressions and observances. But the record also shows justifications proposed to limit these religious observances, and counter-arguments offered by the judges. The justifications and judgments demonstrate a deliberation over learner religious observances on issues of conformity, freedom and religious diversity. This essay shows that while the value of religion education as prescribed by the NPRE is still under debate, the dress observances of some learners are extending its articulation as far as religious observances in concerned. They are dramatically showing religious diversity at schools.

\section{THE NATIONAL POLICY ON RELIGION AND EDUCATION (NPRE) OF 2003}

Academics are divided on the value of the NPRE. Most scholars in education and religious studies support the NPRE with regard to its educational vision,

5 2005. “Durban Teenager Fights School over Nose Stud." Mail \& Guardian, 19 July.

6 Vena V. 2011. "Battle of the dreads rages on". Mail \& Guardian, 15 September.

7 Vena, "Battle of the dreads rages on".

8 2013. "W Cape School Denies Muslim Siblings Entry for Wearing Head Dress", Mail \& Guardian, 15 September.

9 A v. Governing Body, The Settlers High School and Others (3791/00) [2002] ZAWCHC 4 (8 February 2002); MEC for Education: Kwazulu-Natal and Others v. Pillay (CCT 51/06) [2007] ZACC 21; 2008 (1) SA 474 (CC); 2008 (2) BCLR 99 (CC) (5 October 2007); Radebe and Others v. Principal of Leseding Technical School and Others (1821/2013) [2013] ZAFSHC 111 (30 May 2013). 
and they point to its value in introducing and exposing learners to the religious diversity of the country. A second group argues that the NPRE is potentially and actually unconstitutional. They say that it violates the constitutional guarantees for religious observances in schools, ignores the value of confessional education and takes away the right of parents to determine the religious education for their offspring. The learners' observances of religious dress and attire stand between the two positions. Their dress and attire are religious observances that the second group would support, but they are not formal educative expressions which the first group promotes. In the following review, I show how these observances have escaped the attention of scholars writing on the NPRE.

Since the early 1990s, South African religion scholar David Chidester has consistently promoted a new approach to religion education for South African schools emerging out of apartheid. Chidester was actively involved in the formulation of the new policy with Minister of Education Kader Asmal. ${ }^{10} \mathrm{He}$ made a clear distinction between religious instruction that was confessional and religion education that was comparative and educative. Chidester regarded religion education as a core component of citizenship education for the twentyfirst century. It was directed at educating citizens on the diversity of religious beliefs and practices on both national and global levels. ${ }^{11}$ Like the building and transformation of museums, parks and events that commemorated the past and projected a new future, religion education was similarly constituted to celebrate the South African nation. ${ }^{12}$

Working with school teachers over more than a decade, Cornelia Roux in theological studies and Rene Ferguson and Janet Jarvis in education, have shown how teachers can and have created spaces in schools where learners were exposed to the diversity of religions in their schools and in South Africa in general. With regard to religion education, they offer a positive prognosis for the implementation of the NPRE. They recognise the obstacles facing the implementation of the NPRE, but remain hopeful that teachers and learners can be enriched by dialogue, hermeneutical engagement and a sensitivity to diversity. ${ }^{13}$

10 Chidester D. 2002. "Religion Education in South Africa: Teaching and Learning About Religion, Religions, and Religious Diversity". Oslo Coalition on Freedom of Religion and Belief. Online at: http://folk.uio.no/leirvik/OsloCoalition/DavidChidester.htm

11 Chidester D. 2002. Global Citizenship, Cultural Citizenship and World Religions in Religion Education. Cape Town: HSRC.

12 Chidester D. 2008. "Unity in Diversity: Religion Education and Public Pedagogy in South Africa", Numen 55:272-299.

13 Roux C. 2010. "Religion and Human Rights Literacy as Prerequisite for Interreligious Education", in Engebretson K, De Souza M, Durka G and Gearon L (eds). International Handbook of Inter-Religious Education, Part Two. Dordrecht: Springer, 991-1015; Ferguson R. 2011. “Thinking about how Student Teachers Think about Religion, Religious Diversity, Knowledge and Meaning", in Ter Avest I (ed). Contrasting Colours: European and African Perspectives on Education in a Context of Diversity. Amsterdam: Gopher B.V. Publishers, 110-133; Jarvis J. 2013. "Paving the Way to Transformation: Student Teachers' Religious Identity and 
Not all scholars agreed with the policy and its vision for South Africa. Educationists Albertina Ntho-Ntho and Jan Nieuwenhuis pointed to some of the obstacles facing the implementation of the NPRE in schools. Based on the research done by the former, they found school principals deeply committed to their own religious traditions and unable to deal with the diversity that they encountered in schools. Christianity for the most part remained a "moral compass" for principals, teachers and learners. Principals complained that they were not supported or prepared by the Department of Education to implement the new policy. Ntho-Ntho and Nieuwenhuis concluded that principals should be trained in mediation skills to deal with the demands made by a diverse body of learners. ${ }^{14}$

One of the first critical articles on the values of the NPRE was composed by constitutional law expert Rassie Malherbe in 2002. Malherbe commented on the document entitled "Manifesto on Values, Education and Democracy", published by Kader Asmal in 2001. ${ }^{15}$ Malherbe focussed on the proposal made by Roman Catholic priest Albert Nolan in this document that religious observances for specific religious groups should only be performed outside school hours, and that a non-confessional religion education should become part of the school curriculum. Focusing mainly on the former point, Malherbe argued that religious observances at schools were an essential part of the freedom of religion guaranteed by the Constitution of the Republic of South Africa, 1996, in Sections 15(1) and 15(2):

15 Freedom of religion, belief and opinion

(1) Everyone has the right to freedom of conscience, religion, thought, belief and opinion.

(2) Religious observances may be conducted at state or stateaided institutions, provided that -

(a) those observances follow rules made by the appropriate public authorities;

(b) they are conducted on an equitable basis; and

(c) attendance at them is free and voluntary. ${ }^{16}$

According to Malherbe, Section 15(1) was a declaration of the freedom of religion, while $15(2)$ was an elaboration of that freedom. ${ }^{17}$ Religious observances

Religion Education", Alternation: Interdisciplinary Journal for the Study of the Arts and Humanities in Southern Africa (special issue), Research in Religion and Education 10:131-147.

14 Ntho-Ntho AM and Nieuwenhuis J. 2015. "Religion in Education Policy in South Africa: A Challenge of Change", British Journal of Religious Education 1-13.

15 Asmal K. 2001. "Manifesto on Values, Education and Democracy", Ministry of Education, South Africa. Online at: http://www.dhet.gov.za/Reports\%20Doc\%20 Library/Manifesto\%20on\%20Values,\%20Education\%20and\%20Democracy.pdf

16 Constitutions of the Republic of South Africa, 1996. Online at: http://www.gov. za/DOCUMENTS/CONSTITUTION/constitution-republic-south-africa-1996-1

17 Malherbe R. 2002. "The Constitutionality of Government Policy Relating to Conduct of Religious Observances in Public Schools", Journal of South African Law 3:398. 
at state institutions were, thus, an essential manifestation of the freedom of religion. In Malherbe's view, no justification was provided by Nolan or the Manifesto for what Malherbe called a limitation of the freedom of religious practices. According to Malherbe, religious observances at schools should be equitable and voluntary, but they should not be taken out of the regular hours of the school. Malherbe also believed that the use of "equity" and not "equality" in the clause was significant. He saw no obligation on schools to support everyone's prayers. ${ }^{18}$ Furthermore, Malherbe did not recognise the distinction between religion education and religious instruction that was made by Nolan in his presented, and adopted in the NPRE in 2003. Ignoring this distinction, he believed that religion education should be voluntary since it would potentially impose a perspective that was not shared by learners and their parents. ${ }^{19}$

The key points made by Malherbe in 2002 have been further elaborated and developed by others in their response to the NPRE. Raj Mestry, from the Department of Education at the University of Johannesburg, found the policy on religious observances "vague" and without "specific direction", and thus not binding. ${ }^{20}$ Education expert Johannes L van der Walt and his fellow researchers reminded readers that the government had initially accepted that School Governing Bodies would be responsible for determining religious education policy at schools. ${ }^{21}$ They believed that when Kader Asmal became the Minister of Education in 1999, he reneged on this promise by shifting the focus from the rights of parent to the inculcation of common values. Erika Serfontein, a professor of law, follows Malherbe's hint that the state may be using religion education for its own ends, observing that "neither the state nor schools are allowed to impose a set of multi-religious convictions on individual learners" ${ }^{22}$ The NPRE, Serfontein maintains, promotes a set of common humanistic values in contravention of both the constitution and international law. ${ }^{23}$ It spreads a "dull uniformity" rooted in secularism. Its approach to religion is not based on "religious views" but a general outlook that stresses a "comprehensive and fundamental orientation in the world." ${ }^{24}$ Such values, Serfontein argues,

18 Malherbe, "The Constitutionality of Government Policy", 408.

19 Malherbe, "The Constitutionality of Government Policy", 405.

20 Mestry R. 2006. "The Constitutional Rights to Freedom of Religion in South African Primary Schools", Australia \& New Zealand Journal of Law E Education 12(2):63-64.

21 Van der Walt J, Wolhuter CC and Potgieter FJ. 2009. "Sosiale Kapitaalskepping deur middel van Die Suid-Afrikaanse Beleid oor Godsdiens in Die Onderwys (2003): 'n Skriftuurlik-Prinsipiële Beoordeling" [Social Capital Creation By means of the South African Policy on Religion in The Education (2003): A Textual Principal Evaluation], Tydskrif vir Christelike Wetenskap [Journal for Christian Scholarship] 45(1/2):226; Department of Education, Republic of South Africa. 1995. "White Paper on Education and Training." Online at: http://www.education.gov.za/ LinkClick.aspx?fileticket=855fT9w3A2U\%3D\&tabid=191\&mid=484

22 Serfontein EM. 2014. "Education and Religion in South Africa: Policy Analysis and Assessment Against International Law", Journal of Law and Criminal Justice 2(1):129.

23 Serfontein, "Education and Religion in South Africa", 121-122.

24 Serfontein, "Education and Religion in South Africa", 127. 
are harmful to learners: "a learner['s] human dignity is harmed when he/she is ignored or his/her religious heritage based on religious values is demeaned [sic] to common values." 25

Serfontein's criticism of "dull" common values is matched by other critics of the NPRE who believe that the state should allow confessional education in schools. Van der Walt, Potgieter and Wolhuter claim that parents in many parts of the world have rejected a multicultural approach to religion education. They believe that values are learnt through deep immersion in a religious tradition, and do not see how the policy could prepare learners for church, and for social and civic engagement. ${ }^{26}$ Moreover, in another publication in this debate, Van der Walt takes exception to the implicit definition of religion used in the NPRE. Here, he prefers Rudolf Otto's definition that stresses the numinous dimension of religion in contrast with the NPRE, which leaves out the experience of the holy. ${ }^{27}$ In an earlier article with Stuart Fowler, Van der Walt favours dialogue that would mediate "different visions of the good society" in schools. ${ }^{28}$ In this dialogue, Van der Walt wants to bring "universal" norms to the school "for social life that are grounded in the revelation of God in Christ." ${ }^{29}$ Another commentator on the NPRE, canon law expert Pieter Coertzen, has argued that the new policy deprived religions to pursue education and freedom as envisaged by them. While supporting freedom for all religions in schools, Coertzen also justified some churches being "free to preach the Gospel, for the freedom of conscience to serve God according to his Word and for the guarantee that every anti-Christian power that would threaten the Church in the exercise of its holy ministrations will be resisted and prevented". ${ }^{30}$ This freedom, exercised in the way framed, implies that religious observances should be permitted to oppose or proselytise others in schools.

Scholars who have emphasised the freedom of religious observances at schools say that the NPRE takes away this right. They insist that religious observances and practices, while voluntary, may not be limited or threatened by schools or government policy. Some go so far as to demand a freedom to demonstrate belief, to proselytise and to assert convictions. But in all their deliberations, they have not seriously considered the religious practices of those learners that do not come from a Christian background. They do not discuss the dominance

25 Serfontein, "Education and Religion in South Africa", 127.

26 Van der Walt JL, Potgieter FJ and Wolhuter CC. 2010. "The Road to Religious Tolerance in Education in South Africa (and Elsewhere): A Possible 'Martian Perspective", Religion, State $\mathcal{E}$ Society 38(1):29-52.

27 Van der Walt JL. 2011. "Understanding the Anatomy of Religion as Basis for Religion in Education", HTS Theological Studies 67(3):426-432.

28 Fowler S and Van der Walt JL. 2004. "Chaos and Order in Education", South African Journal of Education 24(1):68.

29 Fowler and Van der Walt, "Chaos and Order in Education", 68.

30 Coertzen P. 2002. "Freedom of Religion and Religious Education in a Pluralistic Society", Nederduitse Gereformeerde Teologiese Tydskrif [Dutch Reformed Theological Journal] 43(1/2):185-196. 
of Christian religious symbols and practices that prevail at schools, and how these would or should be adjusted to the new Constitution and the NPRE. Their arguments are based on absolute constitutional values and principles, on Christian theology or on general educational theory.

Supporters of the NPRE have not addressed the place and nature of religious observances. In their enthusiasm for a new approach to teaching religion prescribed in the NPRE, they have not discussed the value and place of religious observances in assemblies, in schools and classrooms. The typical religion education approach assumes a position of learning about religions, and avoids a discussion of observances that assumes a confessional bearing. ${ }^{31}$ They have so far ignored religious observances that are part of schools, and that the NPRE supports.

As far as the religious observances are concerned, the NPRE stands between its supporters and objectors. It did not follow the suggestions of Catholic theologian Nolan that religious observances should be limited to outside school hours. It unequivocally supports religious observances for learners, and for schools as a whole. It lists several ways in which these may be permitted, including school assemblies, and through learner religious associations in which teachers may be involved. ${ }^{32}$ Moreover, while the policy promotes religion education, it does not completely reject the value of religious instruction. While it states that religious instruction is the "responsibility of the home, the family, and the religious community", it admits that "more needs to be done to strengthen this role [religious instruction]". ${ }^{33}$ In line with this favourable view of religious education, it advises schools to "allow ... the use of their facilities" for programmes of religious instruction. ${ }^{34}$ The NPRE, thus, does not reject the place of religious observances and the value of religious instruction, but favours religion education in the formal curriculum in an unequivocal way.

The religious practices of learners in the form of dreadlocks, nose studs and head coverings provides a unique vantage point to assess the articulation of the NPRE. Such practices are religious observances but they are not formal educational lessons. They deserve the attention of those who support and oppose the NPRE. It will now be shown that their effects in schools, parent body meetings and court judgments are far-reaching. Schools and parents deliberate on the value of religious observances, putting forward arguments and justifications against their manifestation. In contrast, court judgments show how to celebrate or accommodate diversity. The religious observances of learners show an articulation of the NPRE that deserves greater attention.

31 NPRE, para 22.

32 NPRE, para 58-59.

33 NPRE, para 55.

34 NPRE, para 60-62. 


\section{RELIGIOUS OBSERVANCES AT SCHOOLS}

The court records provide an opportunity to look closely at how schools, parent bodies and judges respond to religious dress observances at schools. They include affidavits, justifications, and intermediary and final judgments. These provide information on the religious observances of the learners, and justifications and reasoning offered by schools, parents, parent bodies, and court judges. The first case concerns a girl prohibited from joining her class for wearing Rastafarian dreadlocks. And the second one concerns a girl suspended from school for insisting on wearing a nose stud.

\section{The Lerato Radebe case: Rastafarian dreadlocks}

Lerato Radebe was a 13-year-old girl admitted to Leseding Technical Secondary School. When she presented herself at school in 2013, she was not allowed to join class unless she cut her hair in conformity with the school's dress code. Some mornings, she would be forced to sit in the staff room throughout the day. Supported by the NGO Equal Education, Lerato's father raised the matter with the school, then with the local office of the Department of Education, and then eventually in the Free State High Court.

According to an affidavit presented in court, the school argued that Lerato's dreadlocks were merely a hairstyle and in conflict with the school's code. It also argued that Lerato could not be a Rastafarian, since she attended church where she took Holy Communion and had two siblings who did not wear dreadlocks. The school also contested the representation of Lerato's father, who insisted that she be allowed to wear dreadlocks as a right guaranteed by the Constitution of the Republic of South Africa, 1996. The school maintained that the grandmother raised Lerato and her siblings and also registered Lerato at the school. Unlike the father, who challenged the school, the grandmother seemed more willing to cut Lerato's hair. Apart from the religious justification offered against Lerato, the school in its affidavit also argued that the "machines and chemicals" used in classrooms posed a danger to Lerato's dreadlocks. The school claimed that it attempted to find an alternative school for Lerato, but it also admitted that no other schools in the vicinity would have permitted Lerato to keep her dreadlocks. At a general meeting called by the principal, parents allegedly supported the school's policy on Rastafarianism. At the meeting, parents were allegedly appalled at the consumption of cannabis in Rastafarianism and agreed that the school should not make special provision for dreadlocks. The affidavit of the school was also supported by the local office of the Department of Education. ${ }^{35}$

35 Lerato Radebe, Lehlohonolo Radebe, Selloane Motloung, Equal Education vs. Principal of Leseding Technical School, Chairperson of the School Governing Body, Leseding Technical School, District Director, Lejweleputswa District, Head of Department, Basic Education, Free State, MEC For Education, Free State, Minister of Basic Education, 2013, Case no. 1821, Free State High Court, Respondents' Brief Heads of Argument. 
The matter was heard at the Free State High Court, where Judge Phalatsi ruled that the school should modify its school uniform code and accept learners like Lerato, who chose dreadlocks. The judge urged the school and the Department to deal with the evident discrimination at the school, since "religious intolerance could ruin the country." The judge feared for South Africa if it ignored what "religious intolerance can do ... in our own African continent, as in Northern Mali and Northern Nigeria". ${ }^{36}$ Media reports indicate that learners and parents were unhappy with this decision. ${ }^{37}$

\section{The Sunali Pillay case: Hindu nose stud}

Sunali Pillay at the Durban Girls High School decided to wear a nose stud when she turned fifteen. The school objected to this, as it conflicted with the school's dress code. Sunali's parents supported her choice and asked that the school protect her constitutional right. ${ }^{38}$ The school consulted experts in education and in the Hindu tradition and were assured that the wearing of a nose stud was not a compulsory observance in Hinduism. At a disciplinary hearing held at the school, Sunali was ordered to conform to the dress code at the school. The parents took the matter to the Equality Court in Durban, which upheld the school's decision. The latter found that Sunali did not face unfair discrimination. The matter was then taken up at the High Court and then heard on appeal at the Constitutional Court. There the judges ruled that Sunali had a right to wear a nose stud as part of a cultural right and that the school should modify its dress code for the future. ${ }^{39}$

\section{RELIGIOUS OBSERVANCES IN SOUTH AFRICAN SCHOOLS}

The full court records, including the judgments and the affidavits provided by various parties, provide material for reflection on how these minority religious practices are perceived and received in schools. In this essay, such practices are compared with the religious observances that are permitted by the NPRE. Based on these two cases, the following discussion looks closely at schools and their general response to minority religious observances. From a religious studies perspective, it examines the analysis and recommendations made by

36 Lerato Radebe and others vs. Principal of Leseding Technical School and others, 2013, Judgment of the Court, 13 May 2013.

37 2013. "Leseding learners protest over Radebe's return to school." Online at: http://www.bloemfonteincourant.co.za/leseding-learners-protest-over-radebesreturn-to-school

38 MEC for Education (Kwazulu-Natal), Thulani Cele (School Liaison Officer), Anne Martin (Principal of Durban Girls' High School), Fiona Knight (Chairperson of the Governing Body of Durban Girls' High School) vs. Navaneethum Pillay with amici curiae Governing Body Foundation, Natal Tamil Vedic Society Trust, Freedom of Expression Institute, 2007. Constitutional Court of South Africa, CCT51/06, para 131.

39 MEC for Education (KZN) and others vs. Navaneethum Pillay and others, 2007. Constitutional Court Judgment, CCT 51/06, 5 October. 
the judges for religious and cultural practices. This closer reading of the cases shows how religious diversity is extended at schools, often against the initial wishes of schools and parent bodies. More generally, it shows how diversity that is promoted and supported by the NPRE is articulated through the bodies of learners on schools.

These two cases indicate that learners who adopt religious observances against school norms face censure at school. They confirm media reports that schools have not been very enthusiastic to celebrate the diversity of the country on the bodies of learners, in school uniforms and on school grounds. One of the justifications used for rejecting such practices is that they contradict school codes for uniforms. This was mentioned in both cases elaborated here, and turned down by the judges as insufficient justification to limit the right of learners to observe religious practices. It was also presented as an argument in an earlier case of dreadlocks worn by a learner in the Western Cape, heard by the High Court (Cape of Good Hope Division) in 2002. The school charged the learner of "serious misconduct." The judge in that case challenged the interpretation of the school code offered by the Governing Body of the school and the Head of the Western Cape Education Department. He reminded the respondents (the governing body of the school, the head of the Western Cape Education Department, and the Member of the Executive Council for Education in the Western Province) of the values of the new constitution that should be inscribed in schools. ${ }^{40}$

The idea of a uniform school code is deeply rooted in South Africa, and considered to be a normal part of schooling. Judges and legal scholars who have commented on these cases also assume the value of school uniforms, and recommend only modest departures from the codes ${ }^{41}$ In 2005, the Department of Education issued a set of guidelines on uniforms and expects schools to develop policies accordingly. The guidelines support the value of uniforms, while insisting that the diversity of South African schools be "accommodated." 42 The experience of the learners in these cases suggest that current uniform codes did not fully accept or celebrate the diversity displayed on the bodies on learners. At best, learner observances were expected to be accommodated or accepted under strict conditions. This "tolerant" approach must be contrasted with the value of diversity that is celebrated in the constitution and in the NPRE. Through their bodies, learners at school were disrupting uniform codes set and policed by the

40 A v. Governing Body, The Settlers High School and Others (3791/00) [2002] ZAWCHC 4 (8 February 2002). See para 8, 18, 19 on the charge of misconduct and para 14 and 15 on the values of the constitution.

41 Roos R. 2003. "Physical Appearance of Learners in Public Schools - Antonie V Governing Body, Settlers High School 20024 Sa 738 (C)", Tydskrif vir die SuidAfrikaanse Reg [Journal of South African Law] 4:792-796; Lenta P. 2012. "Is There a Right to Religious Exemptions?" The South African Law Journal 129:303-329.

42 Department of Education, Republic of South Africa. 2005. "National Guidelines on School Uniform, 2005". Online at: http://www.education.gov.za/LinkClick.as px?fileticket=y\%2fNJsnhP8WQ\%3d\&tabid=333\&mid=969 
schools and governing bodies. They were not asking for tolerance, but asserting their rights. In a subtle way, the learners with new religious attire were also calling into question the value of school uniforms that are assumed to be the hallmark of good schooling in South Africa.

Learner religious observances stand in stark contrast to the religious ethos maintained by many schools in South Africa. Most South African public schools maintain Christian religious observances like prayer, hymns and Bible readings. Sometimes, other religious groups are invited to participate as well. But the doctoral dissertation of Ntho-Ntho has pointed to the continuing dominance of Christian symbols and practices in schools. ${ }^{43}$ And this study is supported by a body of scholarship discussed above that argues for further invigouration of religious observances and confessional religious education. Considering this status quo and academic discussion, the schools' attitudes towards nonChristian observances manifested on the bodies of learners begs comment. The schools are not the bastions of secularism that reject religious observances, but rather characterised by a dominant religious ethos of schooling that continues from the past. The controversial practices of the learners thus suggest a struggle over the bodies of learners. Learners with dreadlocks, nose studs and headscarves are confronting prevailing religious observances in a dramatic way. They were using their bodies to observe minority religious practices in schools where mainly Christian religious observances were the norm.

Schools were not unaware of the NPRE, the constitution and their demands. A closer look at their responses shows a deliberation over these religious practices. Schools offered various forms of justifications to support their rejection of the controversial practices. These were often religious justifications that did not consider the convictions of the learners. Leseding Technical Secondary School put forward two arguments against Lerato's dreadlocks. It made a point on the danger posed to the learner due the "machines and chemicals" used in the school. ${ }^{44}$ More significantly, it questioned the veracity of Lerato Radebe's commitment to Rastafarianism. The school questioned the quality of her religious belonging. It pointed out that she "partook of the Holy Communion" at a Roman Catholic church. It further pointed out that her siblings were not Rastafarians. ${ }^{45}$ In a more general claim, Leseding Technical Secondary School referred to the public harm posed by Rastafarian religion and practices. In its affidavit to the Free State High Court, the school defended itself by saying that the dreadlocks worn by Lerato pointed to Rastafarianism which might not be a religion, or might be a harmful religion. ${ }^{46}$ The affidavit of the school reveals a

43 Ntho-Ntho AM. 2013. School Principals Mediating Change: The Case of Religion in Education, PhD Diss, University of Pretoria.

44 Lerato Radebe and others vs. Principal of Leseding Technical School and others, 2013, Respondents' Brief Heads of Argument, para 3.12.

45 Opposing affidavit, Radebe and Others v. Principal of Leseding Technical School and Others (1821/2013) [2013] ZAFSHC 111 (30 May 2013), para 4.14 (d) and (e).

46 Lerato Radebe and others vs. Principal of Leseding Technical School and others, 2013, Respondents' Brief Heads of Argument, para 3.20. 
desperate attempt to delegitimise dreadlocks. In Sunali's case, the Durban Girls High School also doubted the religious value of her decision and practice of a nose stud. It approached an authority in Hinduism who assured them that wearing a nose stud was not a compulsory (my emphasis) practice in Hinduism. ${ }^{47}$ With this distinction between obligatory and non-obligatory practices, the schools determined a religious value for Sunali.

These justifications put forward by the schools border on theological deliberations. The Leseding case shows how the school was using its understanding of religion or Christianity, and imposing its consequences on Lerato. It could not believe that Lerato might be experimenting with a new religion, or that her new religion did not oppose taking Holy Communion. The communal and exclusive understanding of Christianity was used to delegitimise Lerato's faith in Rastafarianism. It was used as a justification to prohibit her from wearing her dreadlocks. The school in Durban also found a justification for prohibiting a nose stud. With the support of an authoritative voice in Hinduism, it created a division between compulsory and non-compulsory religious practices. Apparently, only the former would be allowed to stray from the uniform code of the school. In these two cases, schools and parent bodies are engaging in or using religious deliberations and justifications to judge religious practices observed by learners. Based on these arguments, they are limiting religious observances on the body of learners at their respective schools.

When the cases reached the courts of the country, these justifications and arguments were assessed and debated. The courts generally supported the learners, rejecting the justifications, religious or otherwise, put forward by the schools. They all emphasised the new values of South Africa that should guide uniform codes and school norms. In its judgment on the nose stud case of Sunali, the Constitutional Court went one step further. In contrast with the theological or religious deliberation of the schools, the court introduced a more "secular" way of approaching the matter at hand. In particular, it introduced a distinction between religion and culture into its deliberations on the practices brought by the learners to school. The judgment consisted of two opinions, a majority written by Justice Pius Langa and a minority by Justice Kate O'Regan. Both agreed that Sunali as unfairly treated at her school for wearing a nose stud, but they disagreed on how schools should address new religious practices adopted by learners. Their differences, based on a deliberation of the religion and cultural, are significant for the articulation of the NPRE in schools.

The judges introduced the distinction between religious and cultural practices that they felt ought to be considered by schools. They referred to anthropological literature that argued that cultures and religions were not so easily distinguished from each other. ${ }^{48}$ Nevertheless, they provided a working

47 MEC for Education: Kwazulu-Natal and Others v. Pillay (CCT 51/06) [2007] ZACC 21; 2008 (1) SA 474 (CC); 2008 (2) BCLR 99 (CC) (5 October 2007), para 8.

48 MEC for Education (KZN) and others vs. Navaneethum Pillay and others, 2007. Judgment, para 54. 
definition to help schools think about learners' religious practices on the basis of such distinction: "Without attempting to provide any form of definition, religion is ordinarily concerned with personal faith and belief, while culture generally relates to traditions and beliefs developed by a community." 49 It will be shown that Langa and $\mathrm{O}^{\prime}$ Regan differed on the impact of the distinction between religion and culture.

In leading the majority opinion, Justice Langa saw no material impact of this distinction between religion and culture on the freedom afforded by the Constitution. He stressed that the freedom exercised by a learner to express a cultural practice was equally guaranteed by the Constitution. He stated that the freedom of practising a personal non-obligatory cultural practice was more important that an obligatory cultural practice: "Indeed, it seems to me that it may even be more vital to protect non-obligatory cultural practices ... To limit cultural protection to cultural obligations would, for many cultures and their members, make the protection largely meaningless." ${ }^{50}$ Justice Langa was directly addressing the distinction introduced by the school to limit Sunali's right to wear a nose stud. Rejecting this justification, he directed attention to the dignity of all South Africans promoted by the Constitution and the Equality Act of 2000. More significantly, he used the subtle distinction between religion and culture to stress the protection afforded to individual cultural practices.

In the minority judgment, Justice O'Regan argued that the Constitution's clauses on religion implicitly accepted a difference between beliefs and cultural practices. The relevant clauses were absolute on convictions, but subject to deliberation on cultural practices. ${ }^{51}$ Based on this distinction, the court may have to determine, O'Regan argued, if "the belief is sincerely held in order to decide whether a litigant has established that it falls within the scope of section 15 [protection of religious freedom]." 52 If the matter under consideration was a cultural practice, then it had to be determined if it was generally shared by a community. Justice $\mathrm{O}^{\prime}$ Regan argued that the nose stud worn by Sunali was a culturally shared practice, and should be permitted by the school. Unlike Justice Langa, however, Justice O'Regan did not accept that a voluntary and personal cultural expression enjoyed the same protection of the Constitution and the Equality Act. ${ }^{53}$

Justices $\mathrm{O}^{\prime}$ Regan and Langa offered different guidelines for religious practices at schools. Justice Langa focussed on how cultural practices, both shared and voluntary personal practices, were limited and curtailed in the past in schools.

49 MEC for Education (KZN) and others vs. Navaneethum Pillay and others, 2007. Judgment, para 47.

50 MEC for Education (KZN) and others vs. Navaneethum Pillay and others, 2007. Judgment, para 66.

51 MEC for Education (KZN) and others vs. Navaneethum Pillay and others, 2007. Judgment, para 141-143.

52 MEC for Education (KZN) and others vs. Navaneethum Pillay and others, 2007. Judgment, para 146.

53 MEC for Education (KZN) and others vs. Navaneethum Pillay and others, 2007. Judgment, para 157. 
The new constitution supported diversity in schools, including its uniforms. Justice O'Regan was not less mindful of this context, but her opinion offered a different route for schools. Cultural practices were always shared, and could not be held individually in a "society of atomised communities. ${ }^{54}$ In her judgment, schools should develop policies on how to deal with practices that did not conform to school uniform codes. Exemptions should be offered in a fair manner, and not impinge on the dignity of any learner. Schools may judge religious practices on the basis of a sincerity of belief, its shared provenance, and the degree of importance given to it by leaders within a cultural tradition. ${ }^{55}$

Justices Langa and O'Regan represented and offered two divergent visions for diversity in schools. Justice Langa offered a reading of the Constitution that supported and promoted diversity at a deep individual level, one that was not unjustifiably restricted or curtailed by schools and religious leaders. Justice O'Regan believed in the distinction between beliefs and cultural practices. Practices that were supported by beliefs were guaranteed. But individual cultural practices should be evaluated by schools and religious authorities. In her recommendation, singular cultural practices were not automatically guaranteed freedom of expression. The two opinions signify a struggle over cultural representations in schools - an exuberance on an an individual level, on the one hand, and a guarded resistance to new traditions, on the other.

Constitutional and jurisprudential theorist Patrick Lenta, who has commented on these cases from a liberal legal perspective, agrees with Justice O'Regan on practices that are adopted by individuals on the basis of religious convictions. Lenta does not see the value of protecting cultural practices in the same way as Justice Langa. ${ }^{56}$ Legal theorist Iain Benson responded to Lenta's view, and returned to the issue that Justices Langa and O'Regan opened their judgment on the distinction between religion and culture. Like them, he believed that it was difficult to separate the religious from the cultural in learner practices. ${ }^{57}$ It is important to note that Justice Langa's opinion introduced a subtle difference in the discussion of religion rights. His acceptance of the distinction is directed at the freedom of cultural practices guaranteed by the constitution. He does not dwell on the value of conviction on the part of the individual, or the religious or cultural tradition to which a practice belongs. He focusses on the freedom of the individual to adopt a cultural practice. Justice Langa's argument for supporting individual cultural practices was closely related to the particular historical context of South Africa, which the legal scholars tend to forget as

54 MEC for Education (KZN) and others vs. Navaneethum Pillay and others, 2007. Judgment, para 155.

55 MEC for Education (KZN) and others vs. Navaneethum Pillay and others, 2007. Judgment, para 157.

56 Lenta P. 2007. "Muslim Headscarves in the Workplace and in Schools", The South African Law Journal 124(2):296-319.

57 Benson IT. 2008. "The Case for Religious Inclusivism and the Judicial Recognition of Religious Associational Rights: A Response to Lenta", Constitutional Court Review 1:297-312. 
they deliberate on religious rights. The discrimination faced by learners in the past in South Africa were not limited to religious conviction and practices, but also conceptions and practices of African culture. ${ }^{58}$ Justice Langa's opinion on individual cultural practices addresses this legacy.

Justice Langa's opinion pointed to another important point that flow from these two cases. His judgment identified the individual agency of the learners in adopting a cultural practice: "Indeed, it seems to me that it may even be more vital to protect non-obligatory cultural practices ..." In the Leseding Technical Secondary School case, the records show that Lerato was not following her grandmother or her other siblings in the adoption of dreadlocks. Sunali adopted the nose stud without the knowledge or prior approval of her parents. They echo the literature on uniform dress codes, in general, that learners explore and experiment with their convictions and their practices. Uniforms, particularly their violations, provide an opportunity to express individuality and personality. ${ }^{59}$ Religious observances of individual learners in South Africa pointed to their agency in articulating the NPRE and the Constitution.

\section{CONCLUSION}

Since the promulgation of the NPRE in 2003, a debate has been going on between those who see it as a harbinger of a new future on the teaching of religion in schools, and those who thought that it was unconstitutional for limiting religious observances at schools. This essay has shown that the NPRE, in fact, does not proscribe religious observances, even as it promotes a new approach to teach learners about religion. The debate among academics seems to have ignored the fact that the NPRE gives something to both groups. Given this challenge of religious observances in the policy and the academic debate surrounding it, this chapter has turned attention to the religious practices of learners that have been routinely rejected at schools. As religious observances, they provide a vantage point on how the NPRE has been articulated in schools. With a close reading of court documents in two cases, this chapter shows how learner religious practices were resisted, deliberated upon, and accommodated at the behest of the courts. It points to the disruption caused by these learner practices to uniform school codes, and to standard justifications against suspected religious traditions.

Schools and parent bodies resisted these practices by various kinds of religious and non-religious justifications. These justifications revealed prejudice against

58 Leatt AMJ. 2011. The State of Secularism: Constituting Religion and Tradition Towards a Post-Apartheid South Africa, PhD Diss, University of the Witwatersrand, 86; Gordon RJ. 1991. "Serving the Volk with Volkekunde: On the Rise of South African Anthropology", in Jansen JD (ed). Knowledge and Power in South Africa: Critical Perspectives Across the Disciplines. Johannesburg: Skotaville, 79-97.

59 Garot R and Katz J. 2003. “Provocative Looks: Gang Appearance and Dress Codes in an Inner-City Alternative School", Ethnography 4(3):421-454. 
minority traditions, but also religious justifications imposed upon learners. When presented in courts, these prejudices and innovative justifications were turned down by judges. In the nose stud case, in particular, the judges introduced a distinction between religious convictions, shared practices and individual choices to address this and other religious and cultural practices. This more secular approach did not completely avoid the treacherous ground of religious beliefs, but provided an innovative way of navigating the diversity of South African schools. The majority led the way by emphasising the freedom to be enjoyed for individual cultural and religious practices. A minority opinion allowed schools, parents and religious authorities to control the experiments of freedom of learners. In general, their legal deliberation paved the way for greater diversity of religious practices in schools.

While it might too early to tell if these deliberations in schools and courts will create a more accommodating environment for learners to observe religious practices on their bodies, there is no doubt that these practices have pushed the limits of the articulation of the NPRE. Their practices have put the spotlight on existing religious observances in schools. They have revealed religious and non-religious arguments at schools, and among parents. And they have pointed to new legal distinctions to pave the way for the celebration of cultural and religious diversity at schools. In an unexpected way, the learner practices may be more educative on diversity than many a school lesson on religion or religious education. 